\title{
A Survey on Individual Differences of Open Access Journals
}

\author{
Lalpeki Ralte \\ Department of Psychology, CHRIST (Deemed to Be University), Bangalore, India
}

Email address:

lalpeki.ralte@res.christuniversity.in

\section{To cite this article:}

Lalpeki Ralte. A Survey on Individual Differences of Open Access Journals. International Journal of Psychological and Brain Sciences. Vol. 4, No. 6, 2019, pp. 65-70. doi: 10.11648/j.ijpbs.20190406.12

Received: September 13, 2019; Accepted: December 18, 2019; Published: December 25, 2019

\begin{abstract}
Recently, a large public academic institution in the US ended its subscription to the most influential publisher of academic research. This institution was driven by the principle that scientific knowledge should not be locked up behind paywalls as the costs of publishing have grown over the years. The purpose of this study is to investigate the prospects of publishing and accessing scientific knowledge from Open Access Journals $(\mathrm{OA})$ and to get a general understanding of what aspects to decide on when a research scholar intends to publish in a Scopus indexed Open Access journal. OA journals are freely available with no cost on the internet. They provide unrestricted access to scientific literature to spread recent updates in various disciplines of science and technology. Method: In this study, the researcher has conducted a non-random survey in alphabetical order, 30 Open Access Scopus indexed Psychology journals for the purpose of understanding and comparing their policies and article processing charges. Result: Based on the survey, research scholars can make decisions based on which journals would be viable for publishing their articles looking at these policies. While some of the journals do not have article processing fees some of the journals charge article processing fees.
\end{abstract}

Keywords: Open Access, Scopus, Article Processing Charge, Publishing Policy

\section{Introduction}

Open Access (OA) journals as the word signifies means that it is freely and openly available for anyone to access. Such journals have existed and are available freely online over the internet. Research scientists no longer require access to the latest hard copy of their journals. It is no longer necessary to leave a laboratory and spend lots of time in the library as much of the information needed to do research is available on our own computers. As opposed to traditional journals, which often charge readers hefty fees to access journal content, OA journals provide content for free on the web and charge researchers to publish their findings [5].

"Open Access" is a term that has come to mean a set of policies about publishing, archiving, and disseminating scholarship. Publishing in an Open Access journal must satisfy two conditions according to the Berlin Declaration of 2003. "The author(s) and right holder(s) of such contributions grant(s) to all users a free, irrevocable, worldwide, right of access to, and a license to copy, use, distribute, transmit and display the work publicly and to make and distribute derivative works, in any digital medium for any responsible purpose, subject to proper attribution of authorship, and the right to make small numbers of printed copies for their personal use. And a complete version of the work and all supplemental materials, in an appropriate standard electronic format is deposited and published in at least one online repository using suitable technical standards. This is supported and maintained by an academic institution, scholarly society, government agency, or other wellestablished organization that seeks to enable open access." [14]

When it comes to publishing in journals, it is always a struggle for researchers to decide on whether to publish in OA or traditional well established journals. According to Sarah Conte (2019), there are four factors to look at when deciding on a journal to publish.

Visibility: More people are likely to see your article in OA than traditional journals. According to a study by Kamil Mizera (2013), full-text downloads of OA papers were $89 \%$ higher, PDF downloads were $42 \%$ higher, and unique visitors were $23 \%$ higher than those for subscription-access articles. 
According to another study by Nature (2014), both science and humanities/social science authors revealed that there is a belief that OA publications are read more widely. Although it is still uncertain whether this increase in downloads and visitors translates into an increased citation rate, the greater visibility achieved with OA may allow you to reach potential collaborators more easily.

Cost: Traditional and OA journals charge a small fee at the time of submission to cover editorial and peer review-related costs. The difference arises in the post-acceptance fees. Traditional journals commonly charge per page (often $\$ 100$ 250 each) and/or per colour figure (\$150-1000 each). However, OA journals charge a flat "article processing charge" that can range from $\$ 8$ to $\$ 5000$ (Cell Reports). The other cost is associated with subscriptions, which can be prohibitive, with some academic subscriptions costing as much as $\$ 40,000$ for full online access to articles.

Prestige: Researchers are at times reluctant to publish in OA journals because they may not be as well-known as some of the well-established journals in a given field. According to Conte (2019), the most common reason cited by science and social science authors for deciding not to publish in an OA journal is related to concerns about perceived quality of OA publications. It is true that many academics still place importance on "brand-name" journals because publication in such journals can increase their chances of being promoted, gaining tenure, and obtaining funding for grant proposals.

Speed of publication: About $65-70 \%$ of science authors consider "the speed from acceptance to publication" to be "very important" or "quite important" when deciding which journal to publish in, while approximately $80-85 \%$ of these authors believe that "the speed from submission to first decision" plays a "very important" or "quite important" role in their decision of where to publish. A recent study surveyed 135 journals listed in the Scopus citation index and concluded that the time from acceptance to publication is significantly shorter for OA journals compared with traditional journals [5].

Hence, it may not be required to choose between "strictly OA" and "strictly traditional" journals, as publishing in a hybrid OA journal with a high Impact Factor may provide the best of both worlds that is the high visibility of an OA journal combined with the prestige of a well-known traditional journal.

In addition to this, OA journals have a colour naming system to identify based on publishing models. The common colouring schemes are "green", "gold" and "hybrid" open access. The Gold OA publishers makes all articles and related content available for free immediately on the journal's website. The Green OA is self-archiving by the authors after peer review by the journal. The Hybrid OA has a mixture of Open Access articles and closed access articles.

Literature Review: Publishing companies that print journals have their own business models that they use to generate their revenue. Prosser (2003) had proposed a mechanism whereby authors would pay a publication charge when the paper is made open access on publication and when a charge is not paid, the paper is only made available to subscribers. This resulted in a hybrid journal in which access to each paper would depend on authors' willingness to pay the publication fee. This was a low-risk strategy for the journal's owner as they would still collect subscription revenue. Albert (2006) reviewed and analysed the evolution of the open access (OA) publishing movement and its impact on the traditional scholarly publishing model. She found that the Internet's transformation of information access fuelled interest in reshaping scholarly publishing. Librarians alone advocated for change, until interest in $\mathrm{OA}$ and related initiatives spread to the scientific community, governmental groups, funding agencies, publishers, and the general public.

Chang (2006) summarised information about open access publishing models and analysed strengths, weaknesses, opportunities, and threats (SWOT). He found in his study that open access business models are creating savings in publishing costs, increasing incomes, adopting innovative technologies and controlling the quality of journals. In 2008, Nazim and Devi studied data collected from directories of open access journals and institutional repositories. They evaluated websites of selected institutional repositories and open access journals. They found that among the top 25 open access publishing countries, India ranks 12th for overall number of journals, but drops to 18th for journals with online content. Its position in the list of open access journals was fifth and ranked 12th in the list of countries with registered interoperable archives in the Registry of Open Access Repositories (ROAR).

McCabe and Snyder (2010) present a model of the journals market. They speculated on whether open-access journals are viable in various economic environments. Bjork (2011) studied how open access journals have experimented with innovations concerning ways of organizing peer review, how journals and articles were formatted, and new publishing revenue models. He found that most early OA journals in the 1990s were founded by individual scholars and used a business model based on voluntary work like open-source development of software. From 2002 onwards, professional OA publishing firms used article-processing charges to fund their operations. In recent years, the growth of OA publishing has been facilitated by the availability of open-source software for journal publishing. Walters and Linvill (2011) examined characteristics of 663 OA journals in biology, computer science, economics, history, medicine, and psychology. They compared these journals with impact factors to comparable subscription journals. They found that there is great variation in the size of OA journals. While just 29 percent of OA journals charge publication fees, those journals represent 50 percent of the articles in their study. The findings of their study was that the OA journal landscape is greatly influenced by few key publishers and journals.

According to Solomon and Bjork (2012), Article processing charges (APCs) are a central mechanism for funding open access (OA) scholarly publishing. In 2010, they studied 1,370 journals that published 100,697 articles. They found that average APC was $\$ 906$ (USD) calculated over 
journals and $\$ 904$ (USD) calculated over articles. The price range varied between $\$ 8$ and $\$ 3,900$ USD, with the lowest prices charged by journals published in developing countries and the highest by journals with high - impact factors from major international publishers. Journals in biomedicine represent $59 \%$ of the sample and $58 \%$ of the total article volume. They also had the highest APCs of any discipline.

In 2013, Kozak and Hartley studied over 9,000 OA journals included in the Directory of Open Access Journals. They found that only $28 \%$ charged authors for publishing in their journals. This figure, however, was highest in various disciplines in medicine (47\%) and the sciences (43\%) and lowest in the humanities (4\%) and the arts was zero percent [10]. McCabe and Snyder (2014) used panel data on science journals to circumvent problems plaguing previous studies of the impact of open access on citations. They found that publishing moved from paid to open access increased cites by $8 \%$ on average based on their sample. The benefit was concentrated among top - ranked journals. OA caused a statistically significant reduction in cites to the bottom ranked journals in our sample, leading to the fact that open access may increase competition among articles for readers' attention, generating losers as well as winners.

\section{Method}

The researcher conducted a non-random survey of Scopus indexed Psychology OA journals. The survey is non-random although the survey has enumerated the journals in alphabetical order. The features such as publishing policies, type of Open Access and article processing charges was surveyed and studied on 30 Open Access journals in Psychology. The journals were chosen from approximately 266 existing active Scopus indexed Psychology journals.

\section{Analysis of Open Access Journals in Psychology}

The researcher has surveyed and listed in alphabetical order, 30 Open Access Scopus indexed Psychology journals for the purpose of understanding and comparing their policies and article processing charges in Table 1. These journals have a parent publishing company that has its own publishing policy.

Table 1. OA Scopus indexed psychology journals.

\begin{tabular}{|c|c|c|c|c|}
\hline Serial No. & Name of Journal & Publishing Policy and APC & Parent publishing company & Country of origin \\
\hline 1 & $\begin{array}{l}\text { Advances in Cognitive } \\
\text { Psychology }\end{array}$ & $\begin{array}{l}\text { Behavioral, cognitive, and brain sciences. } \\
\text { Creative Commons license. } \\
\text { Fees: } 300 \text { Euros }\end{array}$ & $\begin{array}{l}\text { University of Finance and } \\
\text { Management in Warsaw }\end{array}$ & Poland \\
\hline 2 & $\begin{array}{l}\text { Aging, Neuropsychology, and } \\
\text { Cognition }\end{array}$ & $\begin{array}{l}\text { All academic subjects. Creative Commons } \\
\text { license. No APC }\end{array}$ & Taylor and Francis & United Kingdom \\
\hline 3 & AIDS Care & $\begin{array}{l}\text { All academic subjects. Creative Commons } \\
\text { license. No APC }\end{array}$ & Taylor and Francis & United Kingdom \\
\hline 4 & Applied Neuropsychology: Adult & $\begin{array}{l}\text { All academic subjects. Creative Commons } \\
\text { license. No APC }\end{array}$ & Taylor and Francis & United Kingdom \\
\hline 5 & Applied Neuropsychology: Child & $\begin{array}{l}\text { All academic subjects. Creative Commons } \\
\text { license. No APC }\end{array}$ & Taylor and Francis & United Kingdom \\
\hline 6 & Applied Psycholinguistics & $\begin{array}{l}\text { All academic content. Creative Commons } \\
\text { license. Fees: Not specified }\end{array}$ & Cambridge University Press & United Kingdom \\
\hline 7 & Applied Psychology & $\begin{array}{l}\text { All academic journals and books. Creative } \\
\text { Commons license. Fees: } \$ 1450 \text { to } \$ 5200 \text { for } \\
\text { full OA. } \$ 600 \text { to } \$ 5000 \text { for hybrid access }\end{array}$ & John Wiley \& Sons & United Kingdom \\
\hline 8 & $\begin{array}{l}\text { Applied Psychology: Health and } \\
\text { Well-being }\end{array}$ & $\begin{array}{l}\text { All academic journals and books. Creative } \\
\text { Commons license. Fees: } \$ 1450 \text { to } \$ 5200 \text { for } \\
\text { full OA. } \$ 600 \text { to } \$ 5000 \text { for hybrid access }\end{array}$ & John Wiley \& Sons & United Kingdom \\
\hline 9 & $\begin{array}{l}\text { Archives of Clinical } \\
\text { Neuropsychology }\end{array}$ & $\begin{array}{l}\text { All academic content. Creative Commons } \\
\text { license. Fees: Not specified }\end{array}$ & Oxford University Press & United Kingdom \\
\hline 10 & The Arts in Psychotherapy & $\begin{array}{l}\text { Publishes all academic journals. Creative } \\
\text { Commons license. Fees: Not specified }\end{array}$ & Elsevier & $\begin{array}{l}\text { United States of } \\
\text { America }\end{array}$ \\
\hline 11 & $\begin{array}{l}\text { Asian Journal of Social } \\
\text { Psychology }\end{array}$ & $\begin{array}{l}\text { All academic journals and books. Creative } \\
\text { Commons license. Fees: } \$ 1450 \text { to } \$ 5200 \text { for } \\
\text { full OA. } \$ 600 \text { to } \$ 5000 \text { for hybrid access }\end{array}$ & John Wiley \& Sons & United Kingdom \\
\hline 12 & $\begin{array}{l}\text { The Australasian Journal of } \\
\text { Organizational Psychology }\end{array}$ & $\begin{array}{l}\text { All academic content. Creative Commons } \\
\text { license. Fees: Not specified }\end{array}$ & Cambridge University Press & United Kingdom \\
\hline 13 & Australian Journal of Psychology & $\begin{array}{l}\text { All academic journals and books. Creative } \\
\text { Commons license. Fees: } \$ 1450 \text { to } \$ 5200 \text { for } \\
\text { full OA. } \$ 600 \text { to } \$ 5000 \text { for hybrid access } \\
\text { All academic journals and books. Creative }\end{array}$ & John Wiley \& Sons & United Kingdom \\
\hline 14 & Australian Psychologist & $\begin{array}{l}\text { Commons license. Fees: } \$ 1450 \text { to } \$ 5200 \text { for } \\
\text { full OA. } \$ 600 \text { to } \$ 5000 \text { for hybrid access }\end{array}$ & John Wiley \& Sons & United Kingdom \\
\hline 15 & $\begin{array}{l}\text { Basic and Applied Social } \\
\text { Psychology }\end{array}$ & $\begin{array}{l}\text { All academic subjects. Creative Commons } \\
\text { license. No APC }\end{array}$ & Taylor and Francis & United Kingdom \\
\hline 16 & $\begin{array}{l}\text { Behavioural and Cognitive } \\
\text { Psychology }\end{array}$ & $\begin{array}{l}\text { All academic content. Creative Commons } \\
\text { license. Fees: Not specified }\end{array}$ & Cambridge University Press & United Kingdom \\
\hline 17 & Biological Psychology & Publishes all academic journals. Creative & Elsevier & United States of \\
\hline
\end{tabular}




\begin{tabular}{|c|c|c|c|c|}
\hline Serial No. & Name of Journal & Publishing Policy and APC & Parent publishing company & Country of origin \\
\hline 18 & BMC Psychology & $\begin{array}{l}\text { Commons license. Fees: Not specified } \\
\text { Publishes Psychology, Human Behaviour and } \\
\text { the Mind. Creative Common License. Fees: } \\
\text { Not specified }\end{array}$ & Springer Nature & $\begin{array}{l}\text { America } \\
\text { United Kingdom }\end{array}$ \\
\hline 19 & $\begin{array}{l}\text { Body Movement and Dance in } \\
\text { Psychotherapy }\end{array}$ & $\begin{array}{l}\text { All academic subjects. Creative Commons } \\
\text { license. No APC }\end{array}$ & Taylor and Francis & United Kingdom \\
\hline 20 & $\begin{array}{l}\text { British Journal of Clinical } \\
\text { Psychology }\end{array}$ & $\begin{array}{l}\text { All academic journals and books. Creative } \\
\text { Commons license. Fees: } \$ 1450 \text { to } \$ 5200 \text { for } \\
\text { full OA. } \$ 600 \text { to } \$ 5000 \text { for hybrid access }\end{array}$ & John Wiley \& Sons & United Kingdom \\
\hline 21 & $\begin{array}{l}\text { British Journal of Developmental } \\
\text { Psychology }\end{array}$ & $\begin{array}{l}\text { All academic journals and books. Creative } \\
\text { Commons license. Fees: } \$ 1450 \text { to } \$ 5200 \text { for } \\
\text { full OA. } \$ 600 \text { to } \$ 5000 \text { for hybrid access }\end{array}$ & John Wiley \& Sons & United Kingdom \\
\hline 22 & $\begin{array}{l}\text { British Journal of Educational } \\
\text { Psychology }\end{array}$ & $\begin{array}{l}\text { All academic journals and books. Creative } \\
\text { Commons license. Fees: } \$ 1450 \text { to } \$ 5200 \text { for } \\
\text { full OA. } \$ 600 \text { to } \$ 5000 \text { for hybrid access }\end{array}$ & John Wiley \& Sons & United Kingdom \\
\hline 23 & $\begin{array}{l}\text { British Journal of Health } \\
\text { Psychology }\end{array}$ & $\begin{array}{l}\text { All academic journals and books. Creative } \\
\text { Commons license. Fees: } \$ 1450 \text { to } \$ 5200 \text { for } \\
\text { full OA. } \$ 600 \text { to } \$ 5000 \text { for hybrid access }\end{array}$ & John Wiley \& Sons & United Kingdom \\
\hline 24 & $\begin{array}{l}\text { British Journal of Mathematical } \\
\text { and Statistical Psychology }\end{array}$ & $\begin{array}{l}\text { All academic journals and books. Creative } \\
\text { Commons license. Fees: } \$ 1450 \text { to } \$ 5200 \text { for } \\
\text { full OA. } \$ 600 \text { to } \$ 5000 \text { for hybrid access }\end{array}$ & John Wiley \& Sons & United Kingdom \\
\hline 25 & $\begin{array}{l}\text { British Journal of Psychology, } \\
\text { psychotherapy, Social Psychology }\end{array}$ & $\begin{array}{l}\text { All academic journals and books. Creative } \\
\text { Commons license. Fees: } \$ 1450 \text { to } \$ 5200 \text { for } \\
\text { full OA. } \$ 600 \text { to } \$ 5000 \text { for hybrid access }\end{array}$ & John Wiley \& Sons & United Kingdom \\
\hline 26 & $\begin{array}{l}\text { British Journal of Social } \\
\text { Psychology }\end{array}$ & $\begin{array}{l}\text { All academic journals and books. Creative } \\
\text { Commons license. Fees: } \$ 1450 \text { to } \$ 5200 \text { for } \\
\text { full OA. } \$ 600 \text { to } \$ 5000 \text { for hybrid access }\end{array}$ & John Wiley \& Sons & United Kingdom \\
\hline 27 & Child Neuropsychology & $\begin{array}{l}\text { All academic subjects. Creative Commons } \\
\text { license. No APC }\end{array}$ & Taylor and Francis & United Kingdom \\
\hline 28 & $\begin{array}{l}\text { Clinical Child and Family } \\
\text { Psychology Review }\end{array}$ & $\begin{array}{l}\text { Publishes Psychology, Human Behaviour and } \\
\text { the Mind. Creative Common License. Fees: } \\
\text { Not specified }\end{array}$ & Springer Nature & United Kingdom \\
\hline 29 & The Clinical Neuropsychologist & $\begin{array}{l}\text { All academic journals and books. Creative } \\
\text { Commons license. Fees: } \$ 1450 \text { to } \$ 5200 \text { for } \\
\text { full OA. } \$ 600 \text { to } \$ 5000 \text { for hybrid access } \\
\text { All academic journals and books. Creative }\end{array}$ & John Wiley \& Sons & United Kingdom \\
\hline 30 & Clinical Psychologist & $\begin{array}{l}\text { Commons license. Fees: } \$ 1450 \text { to } \$ 5200 \text { for } \\
\text { full OA. } \$ 600 \text { to } \$ 5000 \text { for hybrid access }\end{array}$ & John Wiley \& Sons & United Kingdom \\
\hline
\end{tabular}

The researcher further classified the above survey of Psychology OA journals based on the parent publishing company, licence, APC, subject area and colour naming scheme they follow in Table 2.

Table 2. Survey of journals based on the parent publishing company, licence, APC, domain and colour naming scheme.

\begin{tabular}{|c|c|c|c|c|c|c|}
\hline Parent Publishing Name & $\mathbf{O A}$ & $\begin{array}{l}\text { Hybrid } \\
\text { Access }\end{array}$ & Licence & APC & Domain & $\begin{array}{l}\text { Colour Naming } \\
\text { scheme }\end{array}$ \\
\hline $\begin{array}{l}\text { University of Finance and } \\
\text { Management in Warsaw }\end{array}$ & Yes & None & Creative Commons & Euro 300 & $\begin{array}{l}\text { Focus on behavioural, } \\
\text { cognitive, and brain } \\
\text { sciences }\end{array}$ & None \\
\hline Taylor and Francis & Yes & Yes & Creative Commons & None & All academic subjects & Gold and Green OA \\
\hline Cambridge University Press & Yes & No & Creative Commons & Not specified & All academic subjects & Gold and Green OA \\
\hline John Wiley \& Sons & Yes & Yes & Creative Commons & $\begin{array}{l}\$ 1450-\$ 5200 \text { for open } \\
\text { access. } \$ 600-\$ 5000 \\
\text { for hybrid access }\end{array}$ & $\begin{array}{l}\text { All academic journals } \\
\text { and books }\end{array}$ & Gold and Green OA \\
\hline Oxford University Press & Yes & No & Creative Commons & Not specified & $\begin{array}{l}\text { All academic journals } \\
\text { and books }\end{array}$ & Gold and Green OA \\
\hline Elsevier & Yes & No & Creative Commons & Up to $\$ 3050$ & All academic journals & Gold and Green OA \\
\hline Springer Nature & Yes & No & Creative Commons & Not specified & $\begin{array}{l}\text { Manuscripts on } \\
\text { psychology, human } \\
\text { behaviour and the mind, } \\
\text { including } \\
\text { developmental, clinical, } \\
\text { cognitive, experimental, } \\
\text { health and social } \\
\text { psychology, as well as } \\
\text { personality and } \\
\text { individual differences }\end{array}$ & Gold OA \\
\hline
\end{tabular}




\section{Result}

An alphabetical ordered non-random sample of 30 Scopus indexed Open Access Journals was taken as a snapshot to understand the journal policies and article processing fees. From Tables 1 and 2, the researcher has analysed that while the above journals are very well known and considered of high prestige and quality, their policies and article processing fees vary. From this classification, psychology research scholars can make decisions based on which journals would be viable for publishing their articles looking at these policies. While some of the journals do not have article processing fees, the journals that do charge fees range from between $\$ 600$ (USD) to as high as $\$ 5200$ (USD). The University of Finance and Management in Warsaw charges a processing fee of up to 300 Euros. The remaining few journals that do not charge a fee for publishing an article according to the survey are Taylor and Francis, Cambridge University Press, Oxford University Press, Elsevier and Springer Nature. However, all these journals will tend to have competitive reviewing methods and standards in choosing articles to publish.

\section{Discussion}

The researcher has surveyed $30 \mathrm{OA}$ indexed journals from Scopus which limits it to only well-known journals that have high Impact Factor and high presence in the scientific community. The survey has also only looked at Psychology journals without taking into account other disciplines. The results from Tables 1 and 2 indicate that psychology research scholars can make decisions based on which journals would be viable for publishing their articles looking at these policies. The article processing fees that the journals charge range from $\$ 600$ (USD) to as high as $\$ 5200$ (USD). Future studies could look at random samples of higher numbers to better understand the trend of OA journals. The researcher also suggests studies that look at OA journals from India and maybe conduct a comparative analysis with international journals.

\section{Conclusion}

Open Access (OA) journals are freely and openly available for anyone to access. Such journals have existed and are available online over the internet. However, it is always a struggle for researchers to decide on whether to publish in OA or traditional well established journals. Previous research has shown that open access business models are creating savings in publishing costs, increasing incomes, adopting innovative technologies and controlling the quality of journals [4], OA journal landscape is greatly influenced by key publishers and journals [13] and that Article processing charges (APCs) are a central mechanism for funding open access (OA) scholarly publishing [12]. While the APC is still charged in most well-known journals, it is up to the researcher to decide on the cost and benefit obtained when it comes to the decision of where they want to publish. Hence, researchers should look at factors such as visibility, cost in terms of article processing fees, prestige of the journal and speed of the publication to help decide on choosing a journal to publish in. A brief non-random sample of 30 OA Psychology journals looks at the different article processing fees and publishing policies based on their business model. This is an attempt to study the factors to look at when a researcher chooses to publish on a Scopus indexed journal.

\section{References}

[1] Albert, K. M. (2006). Open access: implications for scholarly publishing and medical libraries. Journal of the Medical Library Association, 94 (3), 253.

[2] Björk, B. C. (2011). A study of innovative features in scholarly open access journals. Journal of Medical Internet Research, 13 (4), e115.

[3] Figshare. (2019). Author Insights 2014. [online] Available at: https://figshare.com/articles/MSS Author_Insights 2014/120 4999 [Accessed 12 Sep. 2019].

[4] Chi Chang, C. (2006). Business models for open access journals publishing. Online Information Review, 30 (6), 699713. https://doi.org/10.1108/14684520610716171

[5] Conte, S. (2019). Making the Choice: Open Access vs. Traditional Journals|AJE. [online] Aje.com. Available at: https://www.aje.com/arc/making-the-choice-open-access-vstraditional- journals/[Accessed 12 Sep. 2019].

[6] McCabe, M., \& Snyder, C. M. (2004). The economics of open-access journals.

[7] McCabe, M. J., \& Snyder, C. M. (2014). Identifying the effect of open access on citations using a panel of science journals. $\begin{array}{llll}\text { Economic Inquiry, } & 52 & \text { (4), }\end{array}$ https://doi.org/10.1111/ecin.12064

[8] Mizera, K. (2019). Open Access increases citation? A brief overview of two reports|Open Science. [online] Open Science. Available at: https://openscience.com/open-access-increasescitation-a-brief-overview-of-two-reports/[Accessed 12 Sep. 2019].

[9] Nazim, M., \& Devi, M. (2008). Open access journals and institutional repositories: practical need and present trends in India. Annals of library and information studies, 55 (1), 201208.

[10] Kozak, M., \& Hartley, J. (2013). Publication fees for open access journals: Different disciplines-different methods. Journal of the American Society for Information Science and $\begin{array}{llll}\text { Technology, } & 64 & \text { (12), }\end{array}$ https://doi.org/10.1002/asi.22972

[11] Prosser, D. C. (2003). From here to there: a proposed mechanism for transforming journals from closed to open access. Learned publishing, 16 (3), 163-166.

[12] Solomon, D. J., \& Björk, B. C. (2012). A study of open access journals using article processing charges. Journal of the American Society for Information Science and Technology, 63 (8), 1485-1495. https://doi.org/10.1002/asi.22673 
[13] Walters, W. H., \& Linvill, A. C. (2011). Characteristics of open access journals in six subject areas. College \& Research Libraries, 72 (4), 372-392. https://doi.org/10.5860/crl-132

[14] Wulf, K. (2019). A Brief History of History Responding to
Open Access. [online] The Scholarly Kitchen. Available at: https://scholarlykitchen.sspnet.org/2019/02/13/a-brief-historyof-history-responding-to-open-access/[Accessed 12 Sep. 2019]. 